\title{
Evaluation of LipL32 ELISA for Detection of Bovine Leptospirosis in West Java
}

\author{
Sumarningsih, Susanti, Tarigan S \\ Indonesian Research Center for Veterinary Science \\ E-mail: drh.sumarningsih@gmail.com \\ (received 08-03-2017; revised 07-06-2017; accepted 10-06-2017)
}

\begin{abstract}
ABSTRAK
Sumarningsih, Susanti, Tarigan S. 2017. Evaluasi pada LipL32 ELISA untuk deteksi bovine leptospirosis di Jawa Barat. JITV 22(2): 80-90. DOI: http://dx.doi.org/10.14334/jitv.v22i2.1610

Uji diagnosa Leptospirosis yang saat ini digunakan, yaitu micro Agglutination Test (MAT) dan isolasi, merupakan uji yang mahal, sulit dan membutuhkan keahlian khusus. Studi ini bertujuan mengembangkan ELISA berbasis protein rekombinan LipL32 sebagai uji yang mudah dan murah untuk mendeteksi Leptospirosis. DNA pengkode LipL32 dimurnikan dari bakteri Leptospira Pomona, dimasukkan ke dalam plasmid pRSET-C, kemudian diekspresikan sebagai protein poly-histidine-tagged pada sel E.coli BL21. Protein LipL32 berhasil dimurnikan dari supernatan sel lisis dengan Ni-NTA column sebanyak 1mg/l kultur. LipL32 tersebut digunakan sebagai antigen untuk koting dengan konsentrasi final $5 \mu \mathrm{g} / \mathrm{ml}$. Akurasi dari ELISA dievaluasi berdasarkan analisa ROC, dengan membandingkan hasil ELISA dan MAT dari 517 serum sapi. Pada studi ini diketahui bahwa area dibawah kurva (area under curve) sebesar 0.853, sehingga ELISA LipL32 dikategorikan sebagai uji dengan akurasi sedang (moderately accurate), dan menunjukkan bahwa ELISA mampu membedakan serum positive dan negative Leptospirosis. Selain itu, hasil yang diperoleh juga menunjukkan bahwa ELISA LipL32 mampu mendeteksi serum positive MAT spesifik terhadap serovar Hardjo, Grippotyphosa, Tarrasovi, Rachmati and Bataviae. Optimum ambang batas (cut off) untuk ELISA yang ditentukan berdasarkan kurva ROC adalah 0.504, dan diperoleh sensitivitas dan spesifisitas untuk ELISA sebesar 86.0\% dan $69.5 \%$ berturut-turut. Secara keseluruhan dapat disimpulkan bahwa ELISA LipL32 pada penelitian ini dapat digunakan sebagai uji cepat untuk identifikasi antibody anti-Leptospira pada sapi.
\end{abstract}

Kata Kunci: ELISA, LipL32, Leptospirosis, Bovine

\section{ABSTRACT}

Sumarningsih, Susanti, Tarigan S. 2017. 2017. Evaluation of LipL32 ELISA for detection of bovine leptospirosis in West Java. JITV 22(2): 80-90. DOI: http://dx.doi.org/10.14334/jitv.v22i2.1610

The current diagnosis of leptospirosis, micro Agglutination Test (MAT) and isolation, is expensive, impractical and technically demanding. This study was aimed at developing an ELISA based on recombinant LipL32 as a practical, inexpensive test for Leptospirosis. The DNA encoding LipL32 was isolated from Leptospira pomona, inserted into pRSET-C plasmid then expressed in E.coli BL21 as a poly-histidine-tagged protein. The amount of LipL32 protein, which was purified from the supernatant of lysed cells by a Ni-NTA column, was $1 \mathrm{mg} / \mathrm{l}$ culture. This purified LipL32 was used as the coating antigen at $5 \mu \mathrm{g} / \mathrm{ml}$. The accuracy of ELISA was evaluated based on ROC analysis, by comparing the ELISA and MAT results of 517 bovine sera. Result in this study showed that the area under curve (AUC) was 0.853, which categorised the LipL32 ELISA as a "moderately accurate" test and indicates that the ELISA was able to differentiate positive and negative Leptospirosis serum. The result also showed ELISA LipL32 could detect serum positive MAT to Hardjo, Grippotyphosa, Tarrasovi, Rachmati and Bataviae. The optimal cut off for OD ELISA determined based on ROC curve was 0.504 , and it showed sensitivity and specificity of ELISA LipL32 relative to MAT were $86.0 \%$ and $69.5 \%$, respectively. Overall, the result in this study showed that ELISA LipL32 can be used as a rapid test for identification of anti-Leptospira antibodies in bovine.

Key Words: ELISA, LipL32, Leptospirosis, Bovine

\section{INTRODUCTION}

Leptospirosis is one of the most important diseases both in human and animals. In Indonesia, the outbreak of this disease has been reported in human since the early 1900's and still occurring (Rahmawati 2013). The serological prevalence in animal, especially bovine, is high (Susanti et al. 2008). Although being endemic in Southeast Asia especially Indonesia, the disease is often neglected or under-reported (Costa et al. 2015, Rajapakse et al. 2015). Human as accidental host can get infected from infected animal and contaminated environment. Common maintenance hosts for Leptospira are rodents, bovine and pig. Previous study in ICRIVS using MAT as serology test has reported high seropositivity of Leptospirosis in bovine and other mammals (Kusmiyati et al. 2005). Further, numbers of 
cases was also occurred among livestock farm and abattoir workers (Fang et al. 2015).

The reason for the under-reported cases of leptospirosis is the difficulty in recognizing clinical signs for Leptospirosis, which is not specific and can vary from mild flu-like to severe illness. The standard diagnosis for leptospirosis, MAT and isolations, were impractical and technically demanding. Consequently, only limited laboratories are able to perform these two tests to confirm Leptospirosis infection. The drawbacks of MAT include the continuous maintenance culture of life Leptospira, time consuming, the difficulty in maintaining free-contaminating culture, requirement of high technical skill to perform the assay and difficulty for interpretation of the MAT results (Musso \& La Scola 2013). Despite the fact that MAT has been recommended as a golden standard test, some studies proved the deficiency of MAT as a golden standard test because its sensitivity is too low (Limmathurotsakul et al. 2012). The isolation of Leptospira can be used as a definitive diagnostic method, which demonstrating the presence of Leptospira in clinical sample. However, this method is time consuming, technical demanding and not sensitive compared to other available method. Therefore, many diagnostic methods have been developed as alternative tests to overcome these problems, including immunological and molecular tools (Rajapakse et al. 2015)

LipL32 is the major outer membrane protein of Leptospires, which is highly conserved among pathogenic Leptospira species (Haake et al. 2000). Previous studies indicated that LipL32 protein as a potential candidate for rapid and accurate diagnosis of Leptospirosis (Bomfim et al. 2005). Furthermore, ELISA using recombinant LipL32 has been commercially available for detection of canine leptopsirosis. However the suitability of such test for bovine leptospirosis is yet to be confirmed.

This study was aimed to develop indirect ELISA using recombinant protein LipL32 for detection of antiLeptospira antibodies in bovine, and evaluate the performance by comparing this ELISA LipL32 to the MAT results.

\section{MATERIALS AND METHODS}

\section{Preparation of recombinant LipL32 protein}

Recombinant LipL32 protein was produced according to previous study (Sumarningsih et. al. 2016) with some modification on expression method. Briefly, a single colony of $E$. coli BL21 cells containing plasmid- pRSET-C-LipL32 was propagated in $10 \mathrm{ml}$ LB broth containing ampicillin $(50 \mu \mathrm{g} / \mathrm{ml})$ and chloramphenicol $(35 \mu \mathrm{g} / \mathrm{ml})$. After overnight incubation at $37^{\circ} \mathrm{C}$, this culture was added into $250 \mathrm{ml}$ fresh $\mathrm{LB}$ broth containing $2 \%$ glucose, ampicillin $(50 \mu \mathrm{g} / \mathrm{ml})$ and chloramphenicol $(35 \mu \mathrm{g} / \mathrm{ml})$. Incubation was continued at $37^{\circ} \mathrm{C}$ until the density (OD600) reached $0.4-0.6$, then the culture was induced by addition of $1 \mathrm{mM}$ isopropylbeta-D- thiogalactopyranoside (IPTG). After another incubation at $37^{\circ} \mathrm{C}$ for 4 hours, the culture was centrifuged at $7000 \mathrm{x} G$ for 30 minutes. The supernatant was discarded and the pellets was collected and kept at $20^{\circ} \mathrm{C}$ until further processing. The cells were disrupted by sonication for 3 minutes at maximum amplitude. The LipL32 was purified from the disrupted cells using a native Ni-NTA purification kit (Fast Start, Qiagen). The purity of recombinant LipL32 protein was analyzed with SDS PAGE and the protein concentration was measured by Bradford assay using bovine serum albumin as standard.

\section{Sequence Analysis}

The plasmid of pRSET-C-LipL32 was purified from E.coli BL21 cells and sent to $1^{\text {st }}$ base (http://www.baseasia.com/dna_sequencing/) for sequencing as described in previous study (Sumarningsih et al. 2016). Amino acid sequences of LipL32 from Leptospira serovar Pomona, Hardjo and Grippotyphosa were obtained from GeneBank with accession number AY609326, AY442332 and AY609327, respectively. All these LipL32 sequences were analyzed using bioinformatics software Geneious (version 7.1.2) and aligned against sequences

P1

(AAKAKPVQKLDDDDDGDDTYKEERHNK) and P2 (LTRIKIPNPPKSFDDLKN-IDTKKL) that has been identified as important epitopes for LipL32 (Lottersberger et al. 2009).

\section{Production of positive and negative control sera for LipL32 ELISA}

Ten calves from a nearby farm were bled and tested for leptospirosis using MAT. After the testing, one calf which was negative for leptospirosis was purchased. About $20 \mathrm{ml}$ bloods were drawn, serum was prepared, aliquoted, kept at -20 and used as negative control serum. The calf was immunized with $1 \mathrm{mg}$ of recombinant LipL32 and montanide ISA $70 \mathrm{M} \mathrm{VG}$ (SEPPIC) as adjuvant. The second immunization was carried out with $6 \times 10^{8}$ formol-inactivated Leptospira hardjo and $2 \mathrm{mg}$ Quil A in 3.2ml PBS. Four weeks after second immunization, the serum was collected and tested with MAT and ELISA using recombinant LipL32 as coating antigen. After confirming that the serum was positive in both tests, $20 \mathrm{ml}$ of blood was drawn, serum was prepared, aliquoted and used as a positive control serum. 


\section{Optimization of ELISA LipL32}

ELISA optimization was performed to determine the optimal concentration of recombinant LipL32 protein as coating antigen for ELISA. Briefly, recombinant LipL32 protein was serially diluted by twofold dilution; start at $12.5 \mu \mathrm{g} / \mathrm{ml}$ to $0.195 \mu \mathrm{g} / \mathrm{ml}$ in carbonatebicarbonate buffer $\mathrm{pH} 9.6$ and $100 \mu$ of this solution was added into microtitre plate. Negative and positive serum control were included as standard for optimization of ELISA LipL32 in this study. Both serum were used with dilution of $1 / 100$ and $1 / 200$ in PBS pH 7.4. HRP-goat anti bovine IgG (Jackson Immuno Research) as secondary antibody was used with dilution $1 / 3000$ and $1 / 6000$ in PBS pH 7.4. After adding the substrate solution and ABTS, the absorbance at wavelength $420 \mathrm{~nm}$ was measured with Spectrophotometer microtitre plate reader.

\section{Sample collection}

Blood samples were collected from 517 bovine (dairy and beef cattle) of various ages in West Java in 2016. The blood samples were handled and processed carefully to prevent hemolysis. The serum was then carefully prepared and stored at $-20^{\circ} \mathrm{C}$ until used.

\section{Micro Agglutination Test (MAT)}

MAT for bovine serum was performed as described in previous study (Sumarningsih et al. 2016). Briefly, panels of antigens were added into serum samples that had been diluted in PBS, pH 7.4 at 1 : 50, $1: 100,1$ : $400,1: 1600$. The panels of antigens consisted of 14 Leptospira serovars including: L. icterohaemorrhagiae, L. javanica, L. celledoni, L. canicola, L. ballum, L. pyrogens, L. cynopteri, L. rachmati, L. australis, L. pomona, L. grippotyphosa, L. hardjo, L. bataviae, and L. tarrasovi. After incubation for 2 hours at $30^{\circ} \mathrm{C}$, the mixture was examined under a dark-field microscope. The MAT titer was determined as the highest serum dilution that agglutinated at least $50 \%$ the life leptospires.

\section{ELISA LipL32 for field bovine sera}

ELISA LipL32 for field sera was performed using microtitre plates (NUNC Maxisorb). Briefly, the plate were coated with diluted recombinant LipL32 protein (5 $\mu \mathrm{g} / \mathrm{ml})$ in carbonate-bicarbonate buffer and incubated overnight at $4^{\circ} \mathrm{C}$. This coating solution was removed and plate was washed twice with PBS-Tween $0.05 \%$.
The well was blocked by adding $150 \mu$ l of blocking buffer (5\% normal goat serum in PBS) and incubated for 2 hours at room temperature. After washing the plate twice, $100 \mu \mathrm{l}$ of diluted bovine serum (1/100) was added into each well and incubated for 1.5 hours at room temperature. The solution was discarded and the plate was washed four times. Goat anti-bovine IgGHRP was added at 1/6000 dilution in PBS (100 $\mu \mathrm{l} /$ well) and incubated for 1.5 hours at room temperature. The solution was discarded and plate was washed four times. Substrate and chromogenic (ABTS) solution) was added, $100 \mu \mathrm{l} /$ well. After incubation at room temperature for 10 minutes, the absorbance (OD ELISA) was read using Spectrophotometer microtitre plate reader at wavelength $420 \mathrm{~nm}$.

\section{Statistical analysis}

Data were analyzed using descriptive statistics. The accuracy of LipL32 ELISA as a serological test was analyzed using a ROC-curve based on MAT as the golden standard. A MAT titre of 1/100 was used as the cut-off for negative and positive for leptospirosis. The Area under curve (AUC) is used as the discriminating power of LipL32 ELISA for positive and negative leptospirosis. The cut-off of the ELISA was determined as the OD at which the test gave the highest sensitivity and specificity. All statistical analyses were carried out using a commercial statistical package.

\section{RESULTS AND DISCUSSION}

\section{Quantity and quality of recombinant LipL32 protein}

The concentration of recombinant LipL32 measured by Bradford assay was $1 \mathrm{mg} / \mathrm{l}$ culture. The quantity of LipL32 protein produced in present study was as low as $1 / 8$ as that in previous study (Sumarningsih et al. 2016). As in previous study, the purity of recombinant protein LipL32 produced in present study was high (see Figure 1.

Recombinant protein LipL32 in this study was successfully purified using a native buffer system. Similar to the previous study which using pRSET-B to express recombinant protein LipL32 as a solubilized protein and revealed that recombinant protein LipL32 was located in the cytoplasm of E. coli (Chalayon et al. 2011). This is in contrast to Leptospira since in this bacteria LipL32 is located in the outer membrane as a dominant lipoprotein (Cullen et al. 2005) 


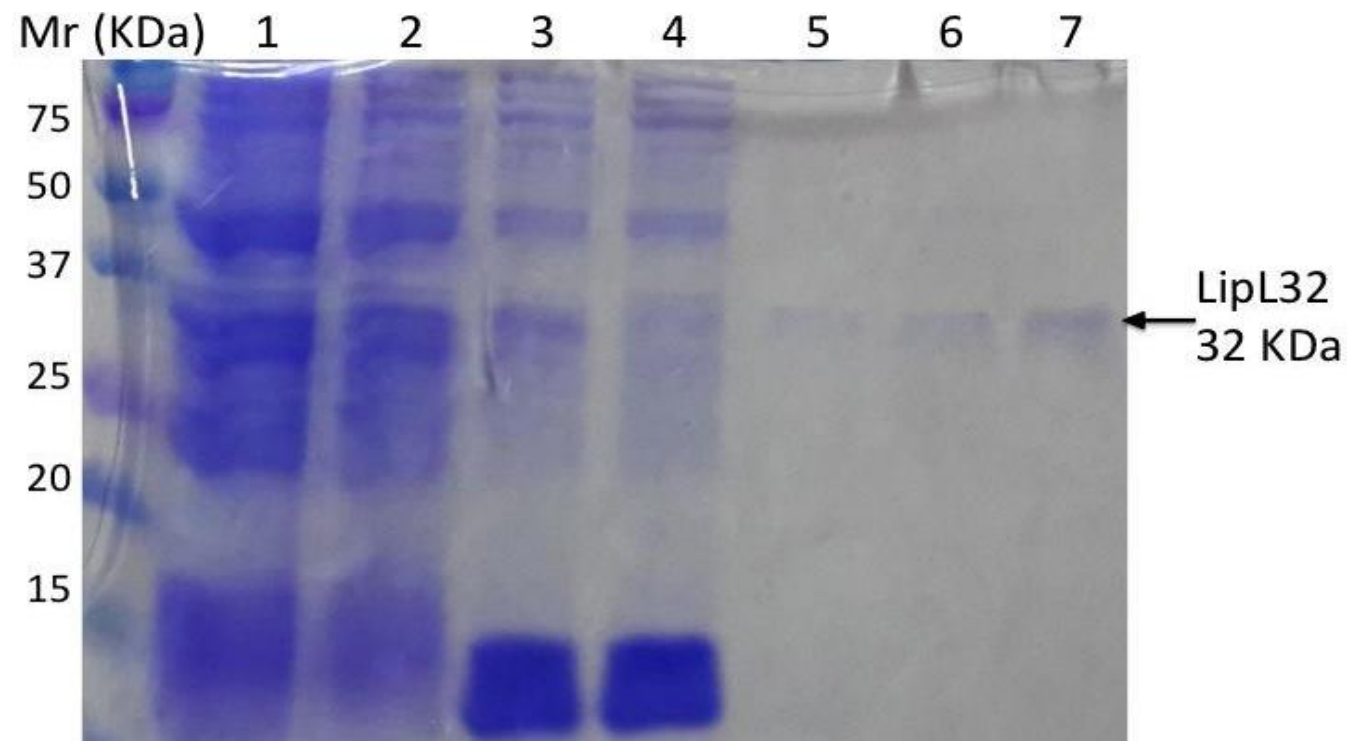

Figure 1. SDS PAGE of recombinant LipL32 protein at different stages of purification. Line 1: uninduced cell, Line 2: induced cell, Line 3: supernatan of lysed cell, Line 4: Flow through, Line 5: Wash buffer, Line 6: LipL32 elution fraction 1, Line 7: LipL32 elution fraction 2. (arrow $\leftarrow:$ LipL32 protein $32 \mathrm{kDa}$ ).

\section{Optimization of ELISA LipL32}

In preliminary experiment, the optimum concentration of recombinant protein Lipl32 was determined by checkerboard titration (Figure 2). The optimum dilutions of secondary antibody and coating antigen were determined based on the OD differences between positive and negative serum for antiLeptospira. Serum anti-Leptospira generated by immunised the bovine using inactivated Leptospira serovar Hardjo was included in this study for comparison.

The OD for positive serum control in ELISA LipL32 using conjugate diluted 1 in 3000 was higher than that when using conjugate 1 in 6000 (Figure 2a vs Figure 2b). However, the background ELISA with the 1 in 3000 diluted conjugate was high as indicated by the increased (above 0.5) OD for negative serum. To obtain a better specificity, a dilution of 1 in 6000 of secondary antibody was used in all assays. Based on the OD difference between positive and negative serum was shown in Figure 2.b, the optimum concentration of LipL32 protein for ELISA coating was determined to be $5 \mu \mathrm{g} / \mathrm{ml}$.

\section{Identification of bovine Leptospirosis using MAT}

MAT was used in this study to determine the status of Leptospirosis. Bovine sera from the field were tested with MAT using panels of 14 Leptospira serovars. The result of MAT summarized in Table 1 showed that 164 of a total 571 serum samples were positive MAT and the titers ranged from 100 to 1600 . This $28.7 \%$ seroprevalence was comparable with that of previous study performed in Indonesia and other country (Kusmiyati et al. 2005, Subharat et al. 2012; AlonsoAndicoberry et al. 2001).

According to previous study on seroprevalence of bovine Leptospirosis in Indonesia, bovine sera that were positive on MAT were dominated against serovar Hardjo (Kusmiyati et al. 2005). However, in this study as shown in table 2, the majority of MAT positive sera were against serovar Grippotyphosa (50\%). Of 164 serum positive MAT, 82 to serovar Grippotyphosa, 71 to serovar Hardjo, 3 to serovar Batavaie, 3 to serovar Rachmati, 1 serum to Tarrasovi and 1 serum to Icterohaemorrhagiae. Two sera were positive for both serovars Grippotyphosa and Bataviae, and 1 serum was positive for Grippotyphosa and Rachmati. 

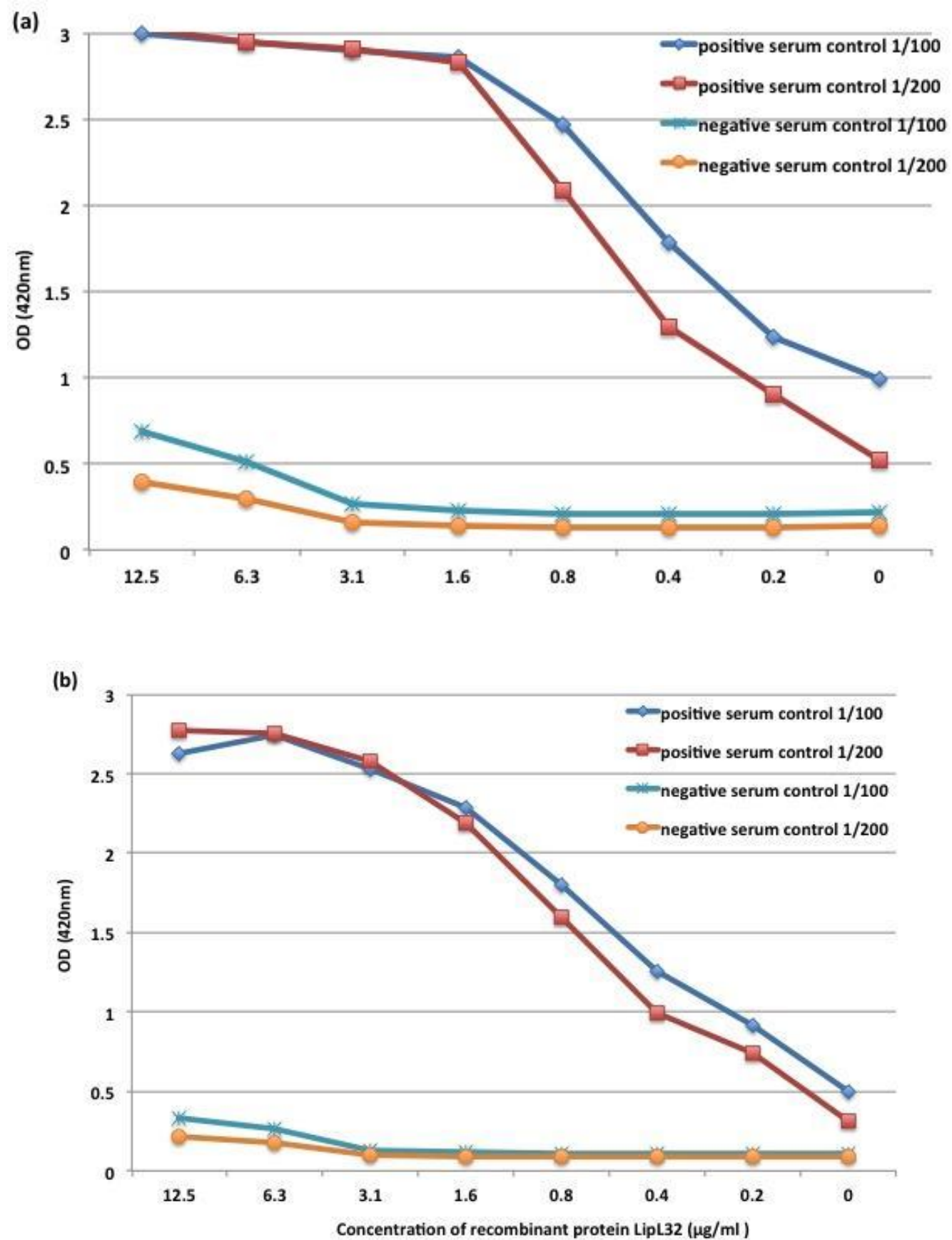

Figure 2. Optimisation of ELISA LipL32; Titration of recombinant protein LipL32 for ELISA coating: (a) ELISA using Goat-antiBovine-IgG-HRP diluted in 1/3000, and (b) ELISA using Goat-anti-Bovine-IgG-HRP diluted in 1/6000. Twofold dilution of LipL32 start at $12.5 \mu \mathrm{g} / \mathrm{ml}$ to $0.195 \mu \mathrm{g} / \mathrm{ml}$ in carbonate-bicarbonate buffer $\mathrm{pH}$ 9.6. 
Table 1. MAT result of field bovine sera

\begin{tabular}{lcc}
\hline \hline MAT results & Number of samples & Percentage (\%) \\
\hline Positive & 164 & 28.7 \\
Negative & 407 & 71.3 \\
\hline Total & 571 & 100 \\
\hline
\end{tabular}

Table 2. Serospecific of bovine sera positive in MAT

\begin{tabular}{lcc}
\hline \hline Serovar & Number of sample & Percentage $(\%)$ \\
\hline Grippotyphosa & 82 & 50.00 \\
Hardjo & 71 & 43.29 \\
Bataviae & 3 & 1.83 \\
Rachmati & 3 & 1.83 \\
Tarrasovi & 1 & 0.61 \\
Icterohaemorrhagiae & 1 & 0.61 \\
Grippotyphosa and Rachmati & 1 & 0.61 \\
Grippotyphosa and Bataviae & 2 & 1.22 \\
\hline Total & 164 & 100
\end{tabular}

\section{Performance of ELISA LipL32 compared to MAT}

The LipL32 ELISA developed in this study was able to differentiate between bovine serum that were positive and negative Leptospirosis. As shown in Figure 3, 95\% confidence intervals of the MAT-negative serum OD was well-separated with that of MAT-positive serum, even with the lowest titer. The mean OD of MATnegative serum was 0.451 . The mean OD of the positive sera with titer of 100,400 and 1600 were $0.742,0.881$ and 0.986 , respectively. Although, the OD was increased by the increasing MAT titer, the differences were not significant.

The ELISA based on recombinant protein is relatively easier and safer to perform compared to MAT. Bomfim et al. (2005) evaluated LipL32 ELISA for detection of bovine Leptospirosis and reported that the agreement was perfect with MAT. The LipL32 ELISA was reported to have $100 \%$ of sensitivity and specificity. LipL32 ELISA was also available commercially from IDEXX, but it is intended to be used for Leptospirosis detection in canine and it need to be imported with high cost for application in Indonesia. This problem motivated us to develop another LipL32
ELISA suitable for detection of bovine Leptospirosis in Indonesia.

The Receiver Operating Characteristic (ROC) curve was used to measure the performance of LipL32 ELISA in this study by comparing the ELISA's OD and MAT results. Results (Figure 4) showed that the area under curve for the ROC curve, which indicates the discriminating power of the test, was 0.853 . A test with $0.7<$ AUC $<0.9$ is categorized as a moderately accurate (Greiner et al. 2000).

ROC curve was also used to determine the cut off, sensitivity and specificity of LipL32 ELISA. Figure 4 and Table 4 showed the optimum cut off OD for ELISA LipL32 in this study was 0.504 . Based on this cut off values, the sensitivity and specificity were $86.0 \%$ and $69.5 \%$, respectively.

\section{Carcass}

Table 4 presented the distribution of OD ELISA LipL32 based on MAT titer. The OD for MAT negative serum was found mostly less than 0.5 , and the OD for bovine serum positive to MAT varied and mostly 


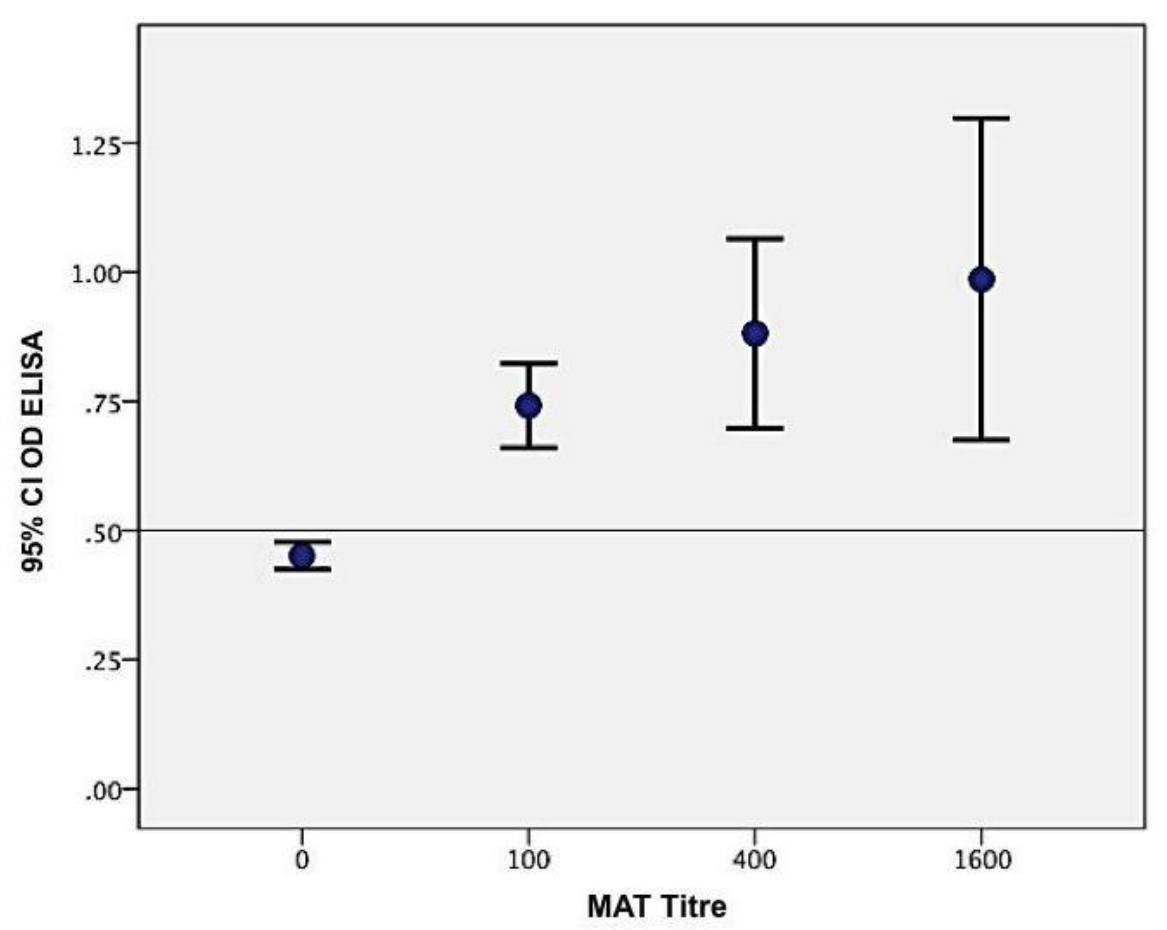

Figure 3. ELISA LipL32 evaluation (with $95 \%$ Confidence Intervals). Graph was generated by plotting the OD values based on the peak titre of MAT (100, 400 and 1600), and peak titre 0 was indicated for MAT negative serum.

Table 3. Analysis of OD_ELISA based on the peak titre of MAT

\begin{tabular}{|c|c|c|c|c|c|c|c|c|}
\hline \multirow{2}{*}{ MAT result (peak titre) } & \multirow{2}{*}{$\mathrm{N}$} & \multirow{2}{*}{ Mean } & \multirow{2}{*}{ Std. Dev } & \multirow{2}{*}{$\begin{array}{l}\text { Std. } \\
\text { Error }\end{array}$} & \multicolumn{2}{|c|}{$\begin{array}{l}95 \% \text { Confidence } \\
\text { Interval for Mean }\end{array}$} & \multirow{2}{*}{ Min } & \multirow{2}{*}{$\operatorname{Max}$} \\
\hline & & & & & $\begin{array}{l}\text { Lower } \\
\text { Bound }\end{array}$ & $\begin{array}{l}\text { Upper } \\
\text { Bound }\end{array}$ & & \\
\hline Negative MAT & 407 & .451 & .206 & .0102 & .431 & .471 & .115 & 1.823 \\
\hline Positive MAT : 100 & 94 & .742 & .301 & .031 & .680 & .803 & .343 & 2.045 \\
\hline 400 & 49 & .881 & .479 & .068 & .743 & 1.019 & .367 & 2.669 \\
\hline 1600 & 21 & .986 & .501 & .109 & .758 & 1.215 & .506 & 2.089 \\
\hline Total & 571 & .555 & .320 & .013 & .529 & .581 & .115 & 2.669 \\
\hline
\end{tabular}

ranged between 0.5-1.0. Some serum with MAT titer 100 and 400 had low OD (less than 0.5). The OD ELISA for all bovine serum with MAT titer 1600 was above 0.5 . The sensitivity of bovine serum in ELISA LipL32 was higher as the titer of MAT increased. Similar finding has been reported by previous study that evaluated the ELISA LipL32 for leptospirosis canine (SNAP Lepto), which is available commercially from IDEXX. The study showed the agreement percentage between MAT and ELISA LipL32 (SNAP Lepto) for serum with MAT titer 100, 200, 400, 800 and 1600 was $62.5 \%, 55 \%, 72.4 \%, 69.8 \%$ and $73.5 \%$, respectively (Curtis et al., 2015). The sensitivity of ELISA LipL32 developed in this study is apparently higher than that study. However, the specificity of our ELISA is lower. These results indicate that LipL32 ELISA is potential to be used as a rapid test for identification of leptospirosis especially as a screening test for anti-Leptospira antibodies in bovine. For a screening approach, the sensitivity of ELISA LipL32 can be improved by lowering the cut off OD. It would decrease the specificity, but it can be overcome by follow-up confirmatory test (Table 5).

In this study, LipL32 ELISA was able detected sera that were positive against various serovars (hardjo, grippotyphosa, tarrasovi, rachmati, bataviae, Tarrasovi and Icterohaemorrhagiae). This is in agreement with fact that LipL32 is highly conserved among serovars of 
pathogenic Leptospira. The ELISA OD was presented in table 6, for sera that were MAT-positive against serovar Grippotyphosa, Hardjo, Bataviae, Rachmati, Tarrasovi, and Icterohaemorrhagiae. One serum which was MAT-positive against both serovar Grippotyphosa and Rachmati has $0.92 \mathrm{OD}$, and the other two sera were MAT-positive against both serovar Grippotyphosa and Bataviae with the mean OD of 0.61. This findings was also supported previous study that reported mice sera anti recombinant LipL32 was successfully recognised and reacted to $32 \mathrm{kDa}$ band (protein LipL32) from whole cell lysate of Leptospira from 17 different serovar (Chalayon et al. 2011). The fact that LipL32 ELISA can detect antibody to different serovars provides further support the usefulness of LipL32 ELISA as a screening test for Leptospirosis

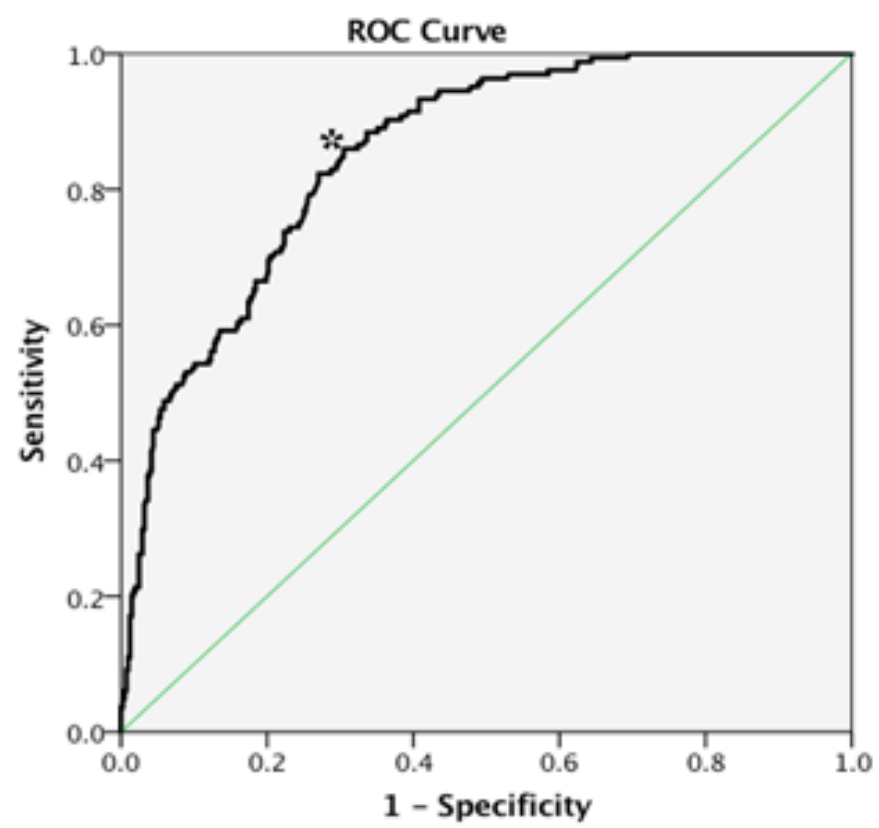

Figure 4. Receiver Operating Characteristic (ROC) Curve of ELISA LipL32. Analysis of ELISA LipL32 using bovine sera in which 164 were MAT positive and 407 were MAT negative. Optimal cut off point is indicated (*) for OD 0.504 with $86 \%$ sensitivity and $69.5 \%$ specificity, and area under curve of 0.853 (95\% CI).

Table 4. Distribution of OD ELISA LipL32 based on MAT titre of bovine serum

\begin{tabular}{|c|c|c|c|c|c|c|}
\hline \multirow{2}{*}{ MAT result } & \multirow{2}{*}{$\mathrm{N}$} & \multicolumn{5}{|c|}{ Frequency of serum sample (f) based on OD ELISA } \\
\hline & & $(0.1-0.5)$ & $(0.5-1.0)$ & $(1.0-1.5)$ & $(1.5-2.0)$ & $(>2.0)$ \\
\hline Negative MAT & 407 & 278 & 119 & 7 & 3 & 0 \\
\hline \multicolumn{7}{|l|}{ Positive MAT } \\
\hline 100 & 94 & 15 & 60 & 17 & 1 & 1 \\
\hline 400 & 49 & 8 & 29 & 5 & 6 & 1 \\
\hline 1600 & 21 & 0 & 13 & 4 & 3 & 1 \\
\hline
\end{tabular}


Table 5. Comparison between the percentage of sensitivity-specificity and cut off OD ELISA LipL32 based on ROC curve analysis

\begin{tabular}{lcc}
\hline \hline Cut Off for OD ELISA & \% Sensitivity (95\% CI) & \% Specificity (95\% CI) \\
\hline 0.400 & 97.0 & 42.8 \\
0.451 & 93.3 & 57.7 \\
0.477 & 90.2 & 63.1 \\
$0.504 *$ & 86.0 & 69.5 \\
0.532 & 75.0 & 75.7 \\
0.544 & 72.6 & 77.6 \\
\hline
\end{tabular}

* Optimal Cut off for OD ELISA LipL32 with $86 \%$ and $69.5 \%$ of sensitivity and specificity, respectively.

Table 6. Analysis of OD_ELISA based on the Leptospira serovar specific

\begin{tabular}{|c|c|c|c|c|c|c|c|c|}
\hline \multirow{2}{*}{ MAT result (serovar specific) } & \multirow{2}{*}{$\mathrm{N}$} & \multirow{2}{*}{ Mean } & \multirow{2}{*}{$\begin{array}{l}\text { Std. } \\
\text { Dev }\end{array}$} & \multirow{2}{*}{$\begin{array}{l}\text { Std. } \\
\text { Error }\end{array}$} & \multicolumn{2}{|c|}{$\begin{array}{l}95 \% \text { Confidence } \\
\text { Interval for Mean }\end{array}$} & \multirow{2}{*}{ Min } & \multirow{2}{*}{$\operatorname{Max}$} \\
\hline & & & & & $\begin{array}{l}\text { Lower } \\
\text { Bound }\end{array}$ & $\begin{array}{l}\text { Upper } \\
\text { Bound }\end{array}$ & & \\
\hline -ve MAT & 407 & .451 & .206 & .010 & .430 & .471 & .115 & 1.823 \\
\hline +ve MAT: Grippotyphosa & 82 & .883 & .475 & .052 & .779 & .988 & .367 & 2.669 \\
\hline Hardjo & 71 & .712 & .254 & .030 & .652 & .773 & .343 & 1.503 \\
\hline Bataviae & 3 & 1.345 & .621 & .358 & -.196 & 2.887 & .860 & 2.045 \\
\hline Rachmati & 3 & .881 & .189 & .109 & .409 & 1.351 & .769 & 1.100 \\
\hline Tarrasovi & 1 & .911 & . & . & . & . & .912 & .912 \\
\hline Icterohaemorrhagiae & 1 & .830 & . & . & . & . & .830 & .830 \\
\hline (Grippo and Rach) & 1 & .917 & . & . & . & . & .918 & .918 \\
\hline (Grippo and Bat) & 2 & .614 & .331 & .234 & -2.356 & 3.583 & .380 & .847 \\
\hline Total & 571 & .555 & .320 & .013 & .529 & .581 & .115 & 2.669 \\
\hline
\end{tabular}

Table 7. Amino acid sequence of important epitope (P1 and P2) from LipL32 protein

\begin{tabular}{lll}
\hline \hline Name & Amino acid sequence of LipL32 & \multicolumn{1}{c}{ Source } \\
\hline$\underline{\text { P1 (151-177) }}$ & AAKAK PVQKL DDDDD GDDTY KEERH NK & $\underline{\text { Lottersberger et al. 2009 }}$ \\
rLipL32_4f2 & AAKAK PVQKL DDDDD GDDTY KEERH NK & Present study \\
L. Pomona & AAKAK PVQKL DDDDD GDDTY KEERH NK & Genebank AY609326 \\
L. Hardjo & AAKAK PVQKL DDDDD GDDTY KEERH NK & Genebank AY442332 \\
L. Grippotyphosa & AAKAK PVQKL DDDDD GDDTY KEERH NK & Genebank AY609327 \\
$\underline{\text { P2 (181-204) }}$ & LTRIK IPNPP KSFDD LKNID TKKL & Lottersberger et al. 2009 \\
rLipL32_4f2 & LTRIK IPNPP KSFDD LKNID TKKL & Present study \\
L. Pomona & LTRIK IPNPP KSFDD LKNID TKKL & Genebank AY609326 \\
L. Hardjo & LTRIK IPNPP KSFDD LKNID TKKL & Genebank AY442332 \\
L. Grippotyphosa & LTRIK IPNPP KSFDD LKNID TKKL & Genebank AY609327 \\
\hline
\end{tabular}




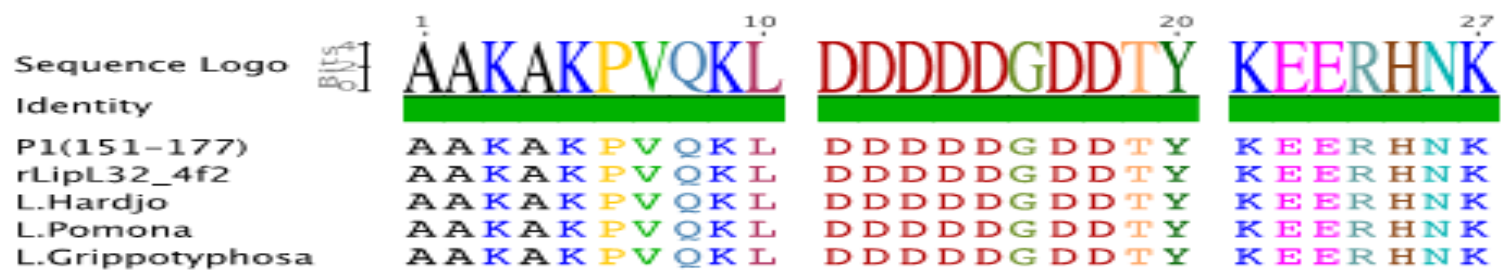

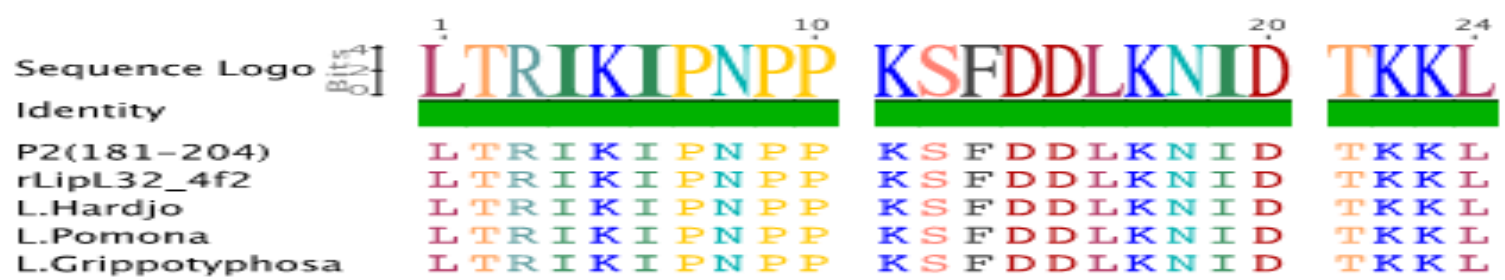

Figure 5. Sequence alignments for the important epitope of LipL32 protein located in amino acids number 151 to 177 (P1) and 181204 (P2). LipL32 protein in this study (rLipL32_4f2) was aligned to P1, P2 and other LipL32 sequences obtained from genebank.

Previous studies performed using simultaneous and parallel solid phase peptide synthesis on derivatives cellulose membranes has been identified two important epitopes of LipL32, P1 and P2 which located in two different regions 151-177 and 181-204, respectively. Both epitopes were highly conserved between pathogenic Leptospira (Lottersberger et al. 2009). Sequences analysis showed $100 \%$ homologous for both peptides (P1 and P2) with recombinant LipL32 protein produced in this study (rLipL32_4f2) and LipL32 protein from Leptospira serovar Pomona, Hardjo, and Grippotyphosa obtained from gene bank with accession number AY609326, AY442332 and AY609327, respectively (Table 7) .

MAT is a gold standard for Leptospirosis and used in this study to determine the true positive and true negative status of Leptospirosis (OIE 2013). However, previous studies found that MAT has many limitation and was imperfect as gold standard for evaluation of the new diagnostic test (Limmathurotsakul et al. 2012). Beside serology assay, PCR targeting LipL32 gene has been developed in order to increase the sensitivity of Leptospirosis detection. The PCR had higher sensitivity and spesificity compared to MAT (De Abreu Fonseca et al. 2006; Ooteman et al. 2006). Thus, bovine serum that positive in ELISA LipL32 can be confirmed by PCR test for eliminating false positive.

\section{CONCLUSION}

The result showed ELISA LipL32 in this study can be used as rapid test for identification of leptospirosis and for screening anti-Leptospira antibodies in bovine. This ELISA LipL32 was able to detect serum MATpositive to hardjo, grippotyphosa, tarrasovi, rachmati, and bataviae. The optimal cut off for OD ELISA determined based on ROC curve was 0.504 , and its sensitivity and specificity of ELISA LipL32 were $86.5 \%$ and $69.5 \%$, respectively.

\section{ACKNOWLEDGMENT}

This work was supported by grant from Indonesian Agency for Agriculture Research and Development (IAARD) Ministry of Agriculture. We also thank BET Cipelang for the assistance in sample collection.

\section{REFERENCES}

Alonso-Andicoberry C, Garcia-Pena FJ, Pereira-Bueno J, Costas E, Ortega-Mora LM. 2001. Herd-level risk factors associated with Leptospira spp. seroprevalence In dairy and beef cattle in Spain. Prev Vet Med. 52:109117.

Bomfim MRQ, Ko AI, Koury MC. 2005. Evaluation of the recombinant Lipl32 in enzyme-linked immunosorbent assay for the serodiagnosis of Bovine Leptospirosis. Vet Microbiol. 109:89-94.

Cerqueira GM, Mcbride AJA, Queiroz A, Pinto LS, Silva ÂF, Hartskeerl RA, Reis MG, Ko AI, Dellagostin OA. 2010. Monitoring Leptospira Strain collections: The need for quality control. Am J Trop Med Hyg. 82:83-87.

Chalayon P, Chanket P, Boonchawalit T, Chattanadee S, Srimanote P, Kalambaheti T. 2011. Leptospirosis Serodiagnosis by elisa based on recombinant outer membrane protein. Trans R Soc Trop Med Hyg. 105:289-297.

Costa F, Hagan JE, Calcagno J, Kane M, Torgerson P, Martinez-Silveira MS, Stein C, Abela-Ridder B, Ko AI. 
2015. Global morbidity and mortality of Leptospirosis: A systematic review. PLoS Negl Tropic Dis. 9:E0003898.

Cullen PA, Xu X, Matsunaga J, Sanchez Y, Ko AI, Haake DA, Adler B. 2005. Surfaceome of Leptospira spp. Infect Immun. 73:4853-4863.

Curtis K, Foster P, Smith P, Monn M, Stillman B, Chandrashekar R, Lappin M, Goldstein R. 2015. Performance of a recombinant Lipl32 based rapid inclinic Elisa (Snap® Lepto) for the detection of antibodies against Leptospira in dogs. Int J App Res Vet Med. 13:182-189.

De Abreu Fonseca C, Teixeira De Freitas VL, Caló Romero E, Spinosa C, Arroyo Sanches MC, Da Silva MV, Shikanai-Yasuda MA. 2006. Polymerase chain reaction in comparison with serological tests for early diagnosis of human Leptospirosis. Trop Med Int Health. 11:16991707.

Fang F, Collins-Emerson JM, Cullum A, Heuer C, Wilson PR, Benschop J. 2015. Shedding and seroprevalence of pathogenic Leptospira spp. in sheep and cattle at a New Zealand abattoir. Zoonoses Public Health. 62:258-268.

Greiner M, Pfeiffer D, Smith RD. 2000 Principles And practical application of the receiver-operating characteristic analysis for diagnostic tests. Prev Vet Med. 45:23-41.

Haake DA, Chao G, Zuerner RL, Barnett JK, Barnett D, Mazel M, Matsunaga J, Levett PN, Bolin CA. 2000. The Leptospiral major outer membrane protein Lipl32 is a lipoprotein expressed during mammalian infection. Infect Immun. 68:2276-2285.

Kusmiyati, Noor SM, Supar. 2005. Leptospirosis pada hewan dan manusia di Indonesia. Wartazoa. 15:213-220.

Limmathurotsakul D, Turner EL, Wuthiekanun V, Thaipadungpanit J, Suputtamongkol Y, Chierakul W, Smythe LD, Day NP, Cooper B, Peacock SJ. 2012. Fool's gold: Why imperfect reference tests are undermining the evaluation of novel diagnostics: a reevaluation of 5 diagnostic tests for leptospirosis. Clin Infect Dis. 55:322-331.
Lottersberger J, Guerrero SA, Tonarelli GG, Frank R, Tarabla H, Vanasco NB. 2009. Epitope mapping of pathogenic Leptospira LipL32. Lett Appl Microbiol. 49:641-645.

Musso D, La Scola B. 2013. Laboratory diagnosis of leptospirosis: A challenge. J Microbiol Immunol Infect, 46:245-252.

[OIE] Office International des Epizooties. 2013. Manual of diagnostic tests and vaccines for terrestrial animals. [Accessed Ferbruary 4th 2016]. http://www.oie.int/manual-of-diagnostic-tests-andvaccines-for-terrestrial-animals/

Ooteman MC, Vago AR, Koury MC. 2006. Evaluation of MAT, IgM ELISA and PCR methods for the diagnosis of human leptospirosis. J Microbiol Methods. 65:247257.

Rahmawati. 2013. Analisis spasial Kejadian Luar Biasa (Klb) kasus leptospirosis di Kabupaten Kulonprogo Tahun 2011. Balaba. 9:53-57.

Rajapakse S, Rodrigo C, Handunnetti SM, Fernando SD. 2015. Current immunological and molecular tools for leptospirosis: diagnostics, vaccine design, and biomarkers for predicting severity. Ann Clin Microbiol Antimicrob. 14:1-8.

Subharat S, Wilson P, Heuer C, Collins-Emerson J. 2012. Longitudinal serological survey and herd-level risk factors for Leptospira spp. serovars Hardjo-bovis and Pomona on deer farms with sheep and/or beef cattle. $\mathrm{N}$ Z Vet J. 60:215-222.

Sumarningsih, Tarigan S, Susanti, Kusmiyati 2016. Recombinant Lipl32 protein for leptospirosis detection in Indonesia. Procedia Chemist. 18:18-25.

Susanti, Kusmiyati, Supar. Seroprevalensi dinamik leptospirosis pada daerah pengembangan sapi perah. 2008. In: Dwiyanto K, Wina E, Priyanti A, Natalia L, Herawati T, Purwandaya B, editors. Prospek industri sapi perah menuju perdagangan bebas 2020. Bogor (Indones): Indonesian Center for Animal Research and Development. p. 372-377. 